\title{
Discussion on Significance of Aesthetic Education in Freedom Education
}

\author{
Furong Du \\ School of Marxis m \\ Northwest Normal University \\ Lan zhou, China
}

\begin{abstract}
Freedom is permanent pursuit of people. The true, the good and the beautiful are the philosophy that embodies the value of freedom. The pursuit of them is the pursuit of freedom. Compared with intellectual education and moral education, aesthetic education isn't valued in Chinese education. However, aesthetic education is crucial for integrated development of people: It improves humanity, stimulates inspiration in natural science and promotes moral self-discipline and people's requirements for beauty and the exertion of people's creativity, finally promotes integrated development of us. Sufficient attentions must be paid to aesthetic education in the future.
\end{abstract}

Keywords-freedom; the true, the good and the beautiful; aesthetic education; integrated development

\section{INTRODUCTION}

Freedom is the ultimate ideal pursued by people. It exists in philosophy and daily life, referring to one of the fundamental ideas and values of western society. American scholar Edler proposes, "There are 120 western philosophical concepts, including 64 big ones. The six highest ones are the true, the good and the beautiful, freedom, equality and justice, among which freedom is the highest". [1] From the perspective of philosophy, the value of freedom embodies in the true, the good and the beautiful. People change objects through cognitive level and demands, produce and transform objects through the law of aesthetics. In this process, people realize the unification of the true, the good and the beautiful and march forward freedom.

We must consider we can implement what kind of moral education. Why we carry out moral education is a fundamental problem. From the perspective of values, the reasons are as follows: First, it is cry ing need. Nowadays, young people think more about themselves instead of others and seldom make contributions for people's happiness. It reflects the malady in the society that needs reestablishment of morality and spirit; second, passing values is a task in civilization in the past, present and future. Values education is needed for existence and development of society and full development of social members; third, people face significant moral issues. Every one of us faces the problem of "how I should live my life". As members in society, we face problems like "how to get along with others", "how to coexist with nature". These reasons urge us to consider educational contents and objectives. The objective of moral education is to cultivate people pursuing the true, the good and the beautiful. Educational contents include moral, intellectual, physical, aesthetic and labor education. Nonutilitarianism and spontaneity of aesthetic make it play an important role in moral, intellectual, physical, aes thetic and labor education.

\section{THE TRUE, THE GOOD AND THE BEAUTIFUL ISTHE PRINCIPLE OF VALUE FOR PEOPLE'S INTEGRATED DEVELOPMENT}

The true is the law of objective world and the principle of value in epistemology. People acquire material goods from natural world to carry out production and living. But the acquisition is not random because people cannot alter and create internal rule of objective world and external criteria of objects. To realize ideals, utilize and transform nature, subjects must grasp law of objective world and intrinsic necessity of objects. In this way, people can realize freedom. Therefore, the true is crucial for the realization of people's freedom.

Except for the principle of value in the true, people must observe the principle of value in the good to realize freedom. The good exists not in external objects but in people and refers to moral ethical norms for people. It is a moral principle of value, ideal required by people and important embodiment of people's freedom and initiative. Without good and evil view, animals behave according to their nature. However, people must behave according to the criterion of the good. It enriches humanity and expands freedom and restricts people's behavior, meanwhile reflects the strength of people's freedom.

Just as the true and the good, the beautiful is an embodiment of people's freedom. There are various definitions of the beautiful in the history of aesthetics. Plato thinks the beautiful is idea. The beautiful is regarded as harmony of forms, the improvement and the pleasure in classicism, rationalism and experientialis $m$ respective. Undoubtedly, people outdo themselves in creating the beautiful and realize freedom. The beautiful represents transcendence and ability of people and personality development, embodies humanity and rationality. 


\section{VALUES AND SIGNIFICANCE OF AESTHETIC EDUCATION}

Aesthetic education is an important part in the values of the true, the good and the beautiful and an indispensable part in values education of freedom, as well as an important means to train talents with integrated development. In school and social education of China, more attentions are paid to intellectual education instead of aesthetic education. However, aesthetic education is special: It is different from seeking knowledge and is unequal to doing good works, let alone making profits. Instead of depending on internal selfconstraint, external stress and allurement of interests or desires, aesthetic education depends on attraction of vivid and interesting audio-visual images and imperceptibly influences educatee. It makes people reach lofty moral realm, "so people have the lofty quality of "never be corrupted by wealth or status, depart from principle due to poverty or humble position, or bow down to power or force" in crucial moment. It orig inates from aesthetic education instead of intellectual education". [2] Cai Yuanpei addresses, "We advocate aesthetic education to make people find emotions lost in music, sculpture, painting and literature".[3] It emphasizes artistic and aesthetic education edifies twisted soul of people and recovers humanity. Specifically, aesthetic education has the following values:

First, beauty embodies people's transcendence of creatural instinctive demand especially life of their own. Behaviors of animals are irrelevant to beauty and depend on their life instinct. Except for life instinct, people have demands for beauty at higher levels. Undeniably, people also have instinctive impulsion. When acquiring means of subsistence, people are restricted by external objects and are driven by material desire, lose dignity and freedom. Aesthetic activities make people get rid of the fetter of material desire, create beauty without utility psychology and purify soul, realize sensory pleasure and obtain spiritual freedom.

Second, beauty is the development of people's personality, capability and self-improvement. People are neither forced nor out of utilitarian needs to carry out aesthetic activities and art activities. They exert creative ability and enrich spiritual world spontaneously through artworks

Third, beauty is an ideal of people. As an ideal of value, beauty cannot be realized completely, but it stimulates people to pursue perfection all the time. The value of beauty is the ultimate ideal of harmony pursued by people. Although we cannot become perfect, beauty continuously stimulates us to pursue perfect aes thetic and art activities: In this process, people create artworks beyond our imag ination; the pursuit of beauty makes people close to perfection and become confident; mean while people realize freedom.

Last, the pursuit of beauty embodies humanity. What's humanity? It is regarded as rationality, labor and freedom, which are tenable and abstract. Humanity embodies in people's happiness, sorrow and loneliness. In real life, our behaviors are restricted. These restrictions are necessary and make us painful. We reduce the restrictions through such ways as art activities to realize freedom. Art activities cannot completely eliminate restrictions, but artworks embody restrictions on people, people's hope and the yearning for freedom and people's tininess. Art activities embody people's existence and freedom.

To sum up, beauty is the symbol of people with integrated development, surpasses the limitation of practice and people's integrated development and gives full play to people's ability.

\section{SIGNIFICANCE OF AEST HETIC EDUCAT ION ON EDUCATION FOR ALL-ROUND DEVELOPMENT}

Educational purpose is people's integrated development. Aris totle thinks the purpose of education is to train cultivated citizens and develop natural instincts to make preparations for good life in the future. Similarly, Rogers proposes in the book of the Freedom to Leam that the world is everchanging and full of contradictions. Education should train people who can adapt to changes and know how to learn. "Those know how to learn and adapt to changes, realize there is no reliable knowledge and only the process of seeking knowledge is reliable are cultivated person." [4] They have fully-developed personality and are highly creative. Meanwhile, "to some extent, people cultivate thems elves", "Freedom refers to the responsibility of people for their choice" [5]. Education should help people's selfrealization, and "make their potential continuously develop, enable them acquire values and dignity in self-realization and try more challengeable and richer experience".

People's integrated development is the basic target of education. Education of aesthetic activities has beneficial effects on people's improvement.

First, aesthetic education improves humanity: people have flesh and blood and the nature to pursue sensual pleasure. But people are social animals with rationality, so they also pursue spiritual freedom and pleasure. Only pursuing sensual pleasure makes people animalized. Only pursuing reason makes people become machine. The two will make people one-sided and comfortless. Aesthetic activities will coordinate them: Set people free in the unification of perception and reason. Aesthetic education transforms perceptual pers on into rational person, sublimates and purifies people. Hegel says, "Schiller holds the opinion that aesthetic education is to turn desire, feeling, impulsion and emotion into rational"[6], to cultivate people with noble sentiment. Meanwhile, it turns rational and boring people into those with integrated development and delight of life. How to spend spare time after work is important for people's emotional state, physical and psychological health. For example, participating recreational activities with aesthetic taste can eliminate fatigue and annoy and contribute to harmony of humanity and free development. From the perspective of individuals, making the best of spare time can learn new knowledge and skills. Aesthetic activities realize all-round development of people. For example, listening to music, painting, practicing calligraphy, appreciating poetry, growing flowers and feeding birds can develop our potential and make our life affluent. 
Second, aesthetic education urges people to explore the truth: aesthetic activities arouse people's enthusiasm to explore the truth, creative imag ination in scientific research and enlighten wisdom as well as expand thinking space. Numerous scientists with great discoveries have aesthetic emotion that man is an integral part of nature when exploring the truth. The emotions relate to aesthetic education received by them as adolescents. Einstein ardently loves music. In 1905, he was inspired when playing the piano, and then he discovered special relativity. He once said, "Most of my scientific achievements are inspired by music". Although we cannot say with aesthetic emotions, we will be certain to have great scientific dis coveries, aesthetic freedom provides sufficient conditions for creative imagination; the nonutilitarianism of aesthetic activities trains people's noble soul. Just as Einstein says, one of the strongest motivations that lead people to art and science is to escape from disgusting vulgarity and desperate depression and get rid of inconstant desire.

Third, aes thetic education promotes moral self-discipline: As perceptual forms that embody freedom of people, art and beauty accumulate the true and the good. It accumulates people's conscience and become free moral mental structure and behavior pattern and makes people more virtuous. As a kind of morality, the good is an external "heteronomy" and gradually becomes people's "self-discipline". Aesthetic education is neither compulsory nor utilitarian. It cultivates people's noble sentiments and moral rule and lets people's personality develop freely. Schiller once said, "There is no other way but to let them become aesthetic people, in order to transform perceptual people into rational people".[7]

Fourth, aesthetic education promotes people to pursue beauty: Individuals shape themselves and transform the whole world according to the law of beauty. With the growth of material wealth, Chinese people pursue external require ments of beauty. It promotes the beauty of appearance in fields and makes our life better. However, the richness of material life is not equal to beauty. Importantly, we should transform creature comfort into higher spiritual pursuit and abandon the desire to be in possession and vanity. With spiritual beauty, we must beautify our behaviors and appearance to make our life beautiful and noble internally and externally.

Fifth, aesthetic education promotes the exertion of creativity: Labor creates beauty, and beauty promotes the development of labor. Under the influence of external environment and internal ideal of beauty, laborers will feel pleased and realize their dignity and value. It greatly arouses laborers' aes thetic creativity.

\section{CONCLUSION}

To sum up, freedom is permanent pursuit of people. Unification of the true, the good and the beautiful is the highest philosophical reflection of freedom. Nowadays, the education includes moral, intellectual, physical, aesthetic and labor education to train people toward freedom. Aesthetic education promotes people's integrated development: It improves personality, urges people to seek the truth and the beautiful and stimulates the inspiration for natural sciences as well as promotes moral self-discipline, meanwhile exerts people's creativity. Stability and spontaneity of aesthetic education are necessary means to realize the value of freedom and train self-discipline, and the most solid psychological foundation to realize people's integrated development. Therefore, in Chinese education, enough attentions must be paid to aesthetic education.

\section{REFERENCES}

[1] [America] Edler, translated by Xi Qinghua: Six Concepts, SDX Joint Publishing Company, 1989 version, page 3-7, 20-23

[2] Cai Yuanpei: Selected Works of Aesthetics of Cai Yuanpei, Peking University Press, 1983 Version, page 164, 221

[3] Cai Yuanpei: Selected Works of Aesthetics of Cai Yuanpei, Peking University Press, 1983 Version, page 251

[4] Che Wenbo, History of Western Psychology, Zhejiang Education Publishing House, 2002, page 563

[5] [British]Rogers: Freedom to Learn, Qu Baokui, Collected Works of Pedagogy Teaching (Volume One), People's Education Press, 1988, page 711

[6] [Germany]Hegel: Volume One of Aesthetics, the Commercial Press, 1979 , page 78

[7] Schiller: On Aesthetic Education of Man, translated by Xu Hengchun, China Federation of Literary and Art Circles Publishing House, 1984, page 29 . 